\title{
Distance education in dentistry in Brazil: a critical STROBE-based analysis
}

Paulo Goberlânio de Barros SILVA(a)

Camila Costa DIAS(a)

Larissa Carvalho MACHADO(a)

Anna Clara Aragão Matos CARLOS(a)

Thinali Sousa DANTAS(a) (1)

Juliana XIMENES(a)

Renata Mota Rodrigues Bitu SOUSA(a)

Fabrício Bitu SOUSA(a)

(a) Centro Universitário Christus, Department of Odontology, Fortaleza, CE, Brazil.

Declaration of Interests: The authors certify that they have no commercial or associative interest that represents a conflict of interest in connection with the manuscript.

Paulo Goberlânio de Barros Silva

E-mail:paulo_goberlanio@yahoo.com.br

https://doi.org/10.1590/1807-3107bor-2021.vol35.0109

Submitted: June 29, 2020

Accepted for publication: March 1, 2021

Last revision: April 23, 2021
Abstract: The COVID-19 pandemic has forced dentistry schools (DSs) to adapt their teaching techniques to digital platforms. Therefore, we aimed to evaluate distance classes in the Brazilian DS curriculum. After an online search of higher education institutions (HEIs) with DS on the e-Ministry of Education (MEC) platform, we included institutions with at least one graduated class to extract the age/localization of the DS, funding, number of authorized seats, MEC-grade, ENADEscore, and workload. HEIs' webpages were consulted to identify the curriculum, subjects offered in the distance education (DE) format, extracurricular programs, scientific events, postgraduate programs, and institutional YouTube channels. Chi-square/Fisher's tests plus binary logistic regression were performed (SPSS 20.0, $\mathrm{p}<0.05$ ). Of the 241 DSs evaluated, 82 (34.0\%) offered distance classes, and a high prevalence was observed in the southeast region $(p<0.001)$ and private HEIs $(p=0.001)$. HEIs with distance classes had lower ENADE scores $(p=0.004)$, lower workload $(p=0.007)$, and higher workload for optional subjects $(p=0.016)$, doctoral programs $(p=0.041)$, specialization courses $(p=0.017)$, and institutional YouTube channels $(p<0.001)$. Southern dental schools $(p<0.001)$, lower workload $(p=0.022)$, optional subjects $(p=0.033)$, and institutional YouTube channels $(p=0.005)$ were independently associated with distance classes. In one-third of the Brazilian DSs, distance classes and institutional YouTube channels were strongly associated variables. The association of distance learning with lower workload and low academic performance draws attention to the need for regulatory bodies for controlling the quality of DE.

Keywords: Schools; Dentistry; Education; Brazil.

\section{Introduction}

Between March and April 2020, several Brazilian states started to adopt quarantine measures, and face-to-face classes were suspended because of the pandemic caused by the 2019 novel coronavirus (SARSCoV-2), responsible for the coronavirus disease 2019 (COVID-19). ${ }^{1,2}$ Therefore, the restrictions imposed on face-to-face classes prompted numerous higher education institutions (HEIs), supported by online technologies, to reinvent and virtualize theoretical content. No higher education teachers working exclusively with in-class teaching were prepared for such an abrupt change in work style, and several teachers 
had difficulties adapting to the virtualization of theoretical content. ${ }^{3}$ However, it is not known when face-to-face classes will fully resume, with projections suggesting that conventional classroom activities might dramatically increase the number of new cases of coronavirus infections in schools. ${ }^{4}$ Thus, it appears that higher education in dentistry will be forced to adapt its teaching methods to the process of distance education (DE) until there is complete resumption of all commercial activities. ${ }^{5,6}$

Some HEIs have already offered DE in dentistry based on the premise that new technologies are indispensable for facing challenges concerning new pedagogical concepts and teaching methodologies. ${ }^{7}$ In Europe, e-learning systems have been already in use for some time in dental schools. ${ }^{8}$ In Brazil, some areas such as oral radiology have already been implementing distance learning methodologies without any significant differences compared with the standard face-to-face method. ${ }^{9}$

For students and teachers, e-learning is a promising way to save time as it cuts down the travel time for school. Similarly, students can work on their courses according to their own schedules. However, some students have problems in comprehending course information that is technical, quantitative, or scientifically oriented. Moreover, course expectations are often unclear, and because of the physical separation between the teacher and student, such problems might be difficult to resolve. ${ }^{10}$ Although the objective of many DE initiatives might increase the learning opportunities for geographically distant learners, teachers have reported that the use of technology may lead to feelings of isolation and alienation. ${ }^{11}$

Nevertheless, classic departmental bureaucracy regarding curricular innovations ${ }^{12}$ has added to inequities in computer and internet access in Brazil. ${ }^{13}$ This further hinders the implementation of new teaching technologies and e-learning systems in dentistry, especially since the acceptance of e-learning depends heavily on the quality of the technology involved..$^{14}$ Considering that our slow journey toward e-learning in dentistry was drastically accelerated by the COVID-19 pandemic, it raises the following question: is Brazil prepared for this new teaching-learning model?

Identifying the pioneers of e-learning in dentistry is indispensable for recognizing the limitations of these systems. Thus, documented studies are important in providing ways to correctly implement DE with pedagogical responsibility. We hypothesize that there are important indicators that improve or worsen the quality of education in e-learning. Since the COVID-19 pandemic has increased the use of e-learning without any advanced planning in dentistry schools (DS), the aim of this study was to identify indicators of DE in the core curriculum of dentistry courses before the COVID-19 pandemic in Brazil and their association with predictive factors and quality indicators.

\section{Methodology}

\section{Type of study and inclusion and exclusion criteria}

This was a cross-sectional study using a secondary data source (documentary) based on the STROBE checklist for cross-sectional studies (Supplementary File 01). ${ }^{15}$ Publicly available data from regulated dentistry courses in Brazil were analyzed, and despite these data not directly involving humans or their information, all national and international ethical precepts were followed, including what establishes Resolution 466/2012 and 510/2016 of the National Health Council.

This study included all HEIs accredited by the Ministry of Education (MEC) of Brazil with undergraduate dentistry courses in activity in 2020. The exclusion criteria were as follows: HEIs with no graduated students (curriculum consolidation), HEIs with unavailable curricular information on their website, and HEIs in which the dentistry course was in the cancellation process.

\section{Data search}

Initially, the online platform of the MEC (e-MEC; https://emec.mec.gov.br) was consulted using the advanced search tool to gather official information on undergraduate dentistry courses in each federal state. The following information was collected: 
institution name and acronym, funding (public or private), start date of the dentistry course, authorized number of seats, operating status, National Exam of Student Performance (ENADE) score, and the course grading given by the MEC. The host state, total workload, and status of the dentistry course were also determined. All data were collected on May 16, 2020, and all evaluated $e$-MEC data were used in this study.

Data related to the curriculum were consolidated in a four-step approach to select items. ${ }^{16}$ First, a thematic review of questionnaires evaluating the study profile in e-learning was accessed to understand the important items required to investigate it. . $11,1,17,18^{-10}$ Second, a teaching expert designed a structured questionnaire based on the information previously described. Third, the items were evaluated by three specialists: a doctor in health education, a doctor in teaching, and a doctor in biostatistics. Fourth, minor item disposition corrections (objectification of responses) were made based on the suggestions of the three specialists, and the questionnaires were launched. This process was conducted over 4 days (one process per day) to minimize fatigue bias, and the meetings were conducted via videoconference due to the COVID-19 pandemic.

The website of each HEI was searched using the full name of the institution on Google Search. The page referring to the dentistry course of each HEI was then searched for the core curriculum, number of subjects, workload, presence of optional subjects, type of curriculum (subject-oriented, modular, and mixed), and the presence of subjects offered in a DE format. Extracurricular services and programs (tutoring, extension, scientific initiation, scientific events, and scientific meetings organized by students) as well as specialization and postgraduate programs were verified on the websites.

The online video-sharing platform YouTube was consulted to verify the presence of teaching channels for each institution by typing the name of each HEI in the search bar. When there was no information on the institution's website about what the research aimed to evaluate, we contacted the institutional e-mail for clarification. All searches were conducted between May 20, 2020 and June 2, 2020.

\section{Training and calibrating the examiners}

Previously, two examiners were trained and calibrated by a gold standard researcher (18 years of PhD in dentistry) to analyze the type of curriculum, extracurricular services and programs, and specialization and postgraduate programs on the websites. First, theoretical training was provided to differentiate between subject-oriented, modular, and mixed-type curricula as well as stricto sensu and lato sensu courses; and to identify extracurricular services and programs (search for official notices).

Second, $10 \%$ of the total sample $(n=55 / 551)$ was randomly selected ("= random()" command in Microsoft Excel, Microsoft Corporation $\left.{ }^{\circledR}\right)$ from the non-included HEIs, and websites were shown by the gold standard researcher only once to the two examiners. The two examiners evaluated the curriculum individually, and data from the analyses were tabulated in Microsoft Excel. The kappa value was calculated by the gold standard researcher (kappa $=0.892)$.

Therefore, the search was performed independently by the two examiners, and when no consensus was reached on the interpretation of data available on the HEI, the gold standard researcher gave a final interpretation.

\section{Statistical analysis}

Data were tabulated in a standard Microsoft Excel spreadsheet and exported to the Statistical Package for the Social Sciences (SPSS, version 20.0, for Windows) software, in which the analyses were performed with a 95\% confidence level.

Continuous variables (total workload, workload of optional subjects, years of activity, and seats offered) were categorized by medians. The other independent variables (region, HEI funding, ENADE score, MEC grade, accreditation request for DE, curriculum type, optional subjects, master's degree programs, doctoral programs, specialization courses, tutoring programs, extension programs, scientific initiation programs, scientific events, scientific meetings organized by students, and institutional YouTube channels) were expressed as absolute and percentage frequencies and crosschecked against 
the availability of distance classes (dependent variable) using Fisher's exact test and Pearson's chi-squared test.

Binary logistic regression (multivariate analysis) with the presence of e-learning was applied using all variables to reduce confounding bias. Adjusted odds ratios (95\% confidence intervals) were plotted.

\section{Results}

\section{Characterization of HEls with dentistry courses in Brazil}

A total of $551 \mathrm{HEI}$ records with dentistry courses were found on the MEC website. Of these institutions, 241 were included in the study. HEIs were excluded for the following reasons: not having fully started the dentistry course $(n=70)$, being in the curriculum consolidation phase $(n=233)$, not providing enough information on their website $(n=3)$, and being in the cancellation process $(n=4)$ (Figure).

Most of the included HEIs were from the southeast region $(n=101,41.9 \%)$, followed by the northeast ( $n=50,20.7 \%)$ and southern $(n=46,19.1 \%)$ regions. The macro-regions with fewer dentistry courses were the north $(n=23,9.5 \%)$ and centralwest $(n=21,8.7 \%)$ regions. The state of São Paulo had the largest number of dentistry courses $(n=53$, $22.0 \%$ ) (Table 1).

On average, the courses have been in activity for $29.7 \pm 26.0$ years, with a median of 20 (5-120) years and offer an average of $140 \pm 151$ seats (median $=100$; 20-2,050). The average total workload of these courses was $4,374 \pm 400 \mathrm{~h}$, with a median of 4253 (3454-5800) h. The workload of optional subjects was $60 \pm 31 \mathrm{~h}$, with a median of 55 (11-258) h.

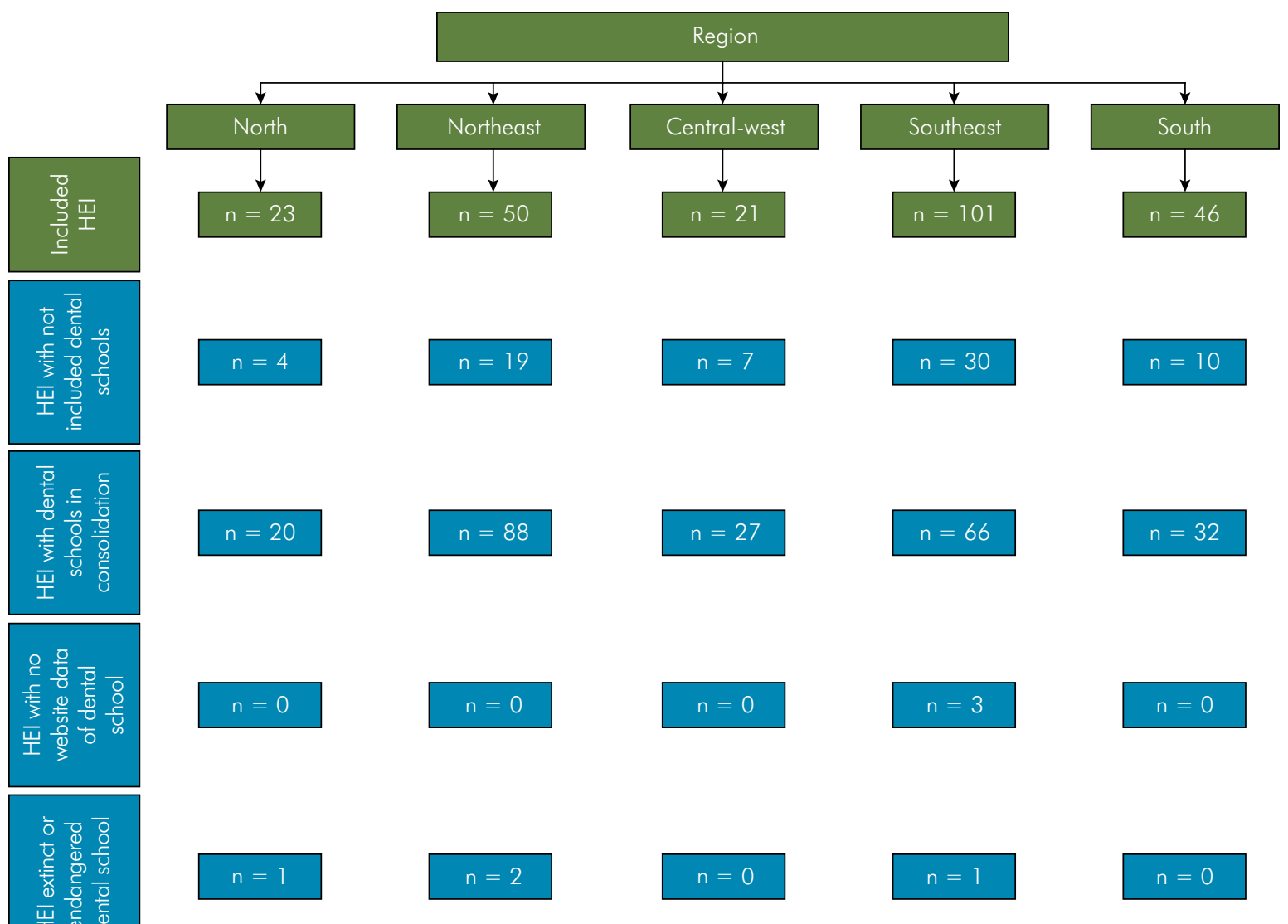

HEl: Higher education institutions.

Figure 1. Distribution of dental schools in Brazil included and excluded of survey. 
Table 1. Macroregional distribution of regulated dentistry courses in Brazil.

\begin{tabular}{|c|c|c|}
\hline Variable & $\mathrm{n}$ & $\%$ \\
\hline \multicolumn{3}{|l|}{ North } \\
\hline Amapá & 2 & 0.8 \\
\hline Pará & 3 & 1.2 \\
\hline Roraima & 1 & 0.4 \\
\hline Acre & 1 & 0.4 \\
\hline Tocantins & 6 & 2.5 \\
\hline Amazonas & 7 & 2.9 \\
\hline Rondônia & 3 & 1.2 \\
\hline Total & 23 & 9.5 \\
\hline \multicolumn{3}{|l|}{ Northeast } \\
\hline Maranhão & 4 & 1.7 \\
\hline Piauí & 4 & 1.7 \\
\hline Ceará & 7 & 2.9 \\
\hline Rio Grande do Norte & 3 & 1.2 \\
\hline Pernambuco & 8 & 3.3 \\
\hline Paraíba & 6 & 2.5 \\
\hline Sergipe & 3 & 1.2 \\
\hline Alagoas & 3 & 1.2 \\
\hline Bahia & 12 & 5.0 \\
\hline Total & 50 & 20.7 \\
\hline \multicolumn{3}{|l|}{ Central-West } \\
\hline Mato Grosso & 5 & 2.1 \\
\hline Mato Grosso do Sul & 3 & 1.2 \\
\hline Goiás/Distrito Federal & 13 & 5.4 \\
\hline Total & 21 & 8.7 \\
\hline \multicolumn{3}{|l|}{ Southeast } \\
\hline São Paulo & 53 & 22.0 \\
\hline Rio de Janeiro & 19 & 7.9 \\
\hline Minas Gerais & 25 & 10.4 \\
\hline Espírito Santo & 4 & 1.7 \\
\hline Total & 101 & 41.9 \\
\hline \multicolumn{3}{|l|}{ South } \\
\hline Paraná & 19 & 7.9 \\
\hline Santa Catarina & 12 & 5.0 \\
\hline Rio Grande do Sul & 15 & 6.2 \\
\hline Total & 46 & 19.1 \\
\hline
\end{tabular}

Data expressed in absolute frequency and percentage.

\section{Dentistry courses with distance classes are significantly concentrated in the southeast region of Brazil}

A total of $82(34.0 \%)$ HEIs had dentistry courses offering DE. As previously mentioned, most dentistry courses in the country were located in the southeastern region of Brazil, with a significantly higher number of courses having DE compared with the other regions $(p<0.001)$. The prevalence of private DSs with DE was 4.37 (95\% CI $=1.77-10.80)$ times higher $(p=0.001)$ than that of public dental schools $(p=0.001)$ (Table 2).

Most dentistry courses were from privately funded HEIs $(n=192,80.7 \%$ ). More than half of the courses were active for 20 years or longer $(n=118,50.2 \%)$ and offered more than 100 seats $(n=145,60.9 \%)$ for dental students. The years of activity $(p=0.111)$ and the number of seats offered ( $p=0.258)$ were not associated with the availability of DE (Table 2).

Regarding quality indicators, most HEIs received a course grade of 4 by the MEC $(n=119,57.8 \%)$ and a score of 3 by ENADE ( $n=77,38.5 \%)$. There was no association between the availability of DE and MEC course grade $(p=0.052)$, but HEIs offering DE had a higher prevalence of low ENADE scores $(p=0.004)$ than HEIs that did not offer DE (Table 2).

\section{Curricular flexibility, presence of postgraduate programs, and institutional YouTube channels are indicators of dentistry courses with distance classes}

Only two HEIs presented accreditation requests for implementing fully distance courses and both had already offered DE $(p=0.070)$. The workload of most dentistry courses was $\leq 4,200 \mathrm{~h}$, and the workload was inversely associated with the presence of DE ( $p=0.007)$. Workload of optional subjects greater than $55 \mathrm{~h}$ was observed in most dentistry courses $(\mathrm{n}=110,51.6 \%$, which was directly associated with the offering of DE $(p=0.016)$ (Table 3).

Most institutions had a subject-oriented curriculum ( $n=124,58.2 \%$ ). Optional subjects were offered by most HEIs ( $n=196,95.2 \%)$, although most HEIs offered specialization courses $(\mathrm{n}=162,68.1 \%) ; 111$ (46.6\%) offered master's degree programs, and only 82 (34.0\%) had doctoral programs. The offering of DE was 
Table 2. Profile of regulated dentistry courses with and without distance classes in Brazil.

\begin{tabular}{|c|c|c|c|c|}
\hline \multirow{2}{*}{ Variable } & \multirow{2}{*}{ Total } & \multicolumn{2}{|c|}{ Distance classes available } & \multirow{2}{*}{$p$-value } \\
\hline & & No & Yes & \\
\hline \multicolumn{5}{|l|}{ Region } \\
\hline North & $23(9.7 \%)$ & $21(13.5 \%)^{*}$ & $2(2.4 \%)$ & $<0.001$ \\
\hline Northeast & $50(21.0 \%)$ & $48(30.8 \%)^{*}$ & $2(2.4 \%)$ & \\
\hline Central-West & 19 (8.0\%) & 17 (10.9\%)* & $2(2.4 \%)$ & \\
\hline Southeast & $100(42.0 \%)$ & 37 (23.7\%) & $63(76.8 \%)^{*}$ & \\
\hline South & 46 (19.3\%) & $33(21.2 \%)^{*}$ & 13 (15.9\%) & \\
\hline \multicolumn{5}{|l|}{ HEl funding } \\
\hline Public schools & 46 (19.3\%) & $40(25.6 \%)^{*}$ & $6(7.3 \%)$ & 0.001 \\
\hline Private schools & $192(80.7 \%)$ & $116(74.4 \%)$ & $76(92.7 \%)^{*}$ & \\
\hline \multicolumn{5}{|l|}{ Years of activity } \\
\hline$\leq 20$ years & 117 (49.8\%) & $82(53.6 \%)$ & 35 (42.7\%) & 0.111 \\
\hline$>20$ years & $118(50.2 \%)$ & 71 (46.4\%) & 47 (57.3\%) & \\
\hline \multicolumn{5}{|l|}{ Seats offered } \\
\hline$\leq 100$ & $93(39.1 \%)$ & $65(41.7 \%)$ & 28 (34.1\%) & 0.258 \\
\hline$>100$ & $145(60.9 \%)$ & 91 (58.3\%) & 54 (65.9\%) & \\
\hline \multicolumn{5}{|l|}{ ENADE score } \\
\hline 1 & $8(4.0 \%)$ & $6(4.4 \%)$ & $2(3.0 \%)$ & 0.004 \\
\hline 2 & 51 (25.4\%) & $30(22.2 \%)$ & 21 (31.8\%)* & \\
\hline 3 & 77 (38.3\%) & $46(34.1 \%)$ & 31 (47.0\%)* & \\
\hline 4 & $52(25.9 \%)$ & $46(34.1 \%)^{*}$ & $6(9.1 \%)$ & \\
\hline 5 & $13(6.5 \%)$ & $7(5.2 \%)$ & $6(9.1 \%)$ & \\
\hline \multicolumn{5}{|l|}{ MEC grade } \\
\hline 3 & 70 (34.0\%) & 40 (30.1\%) & 30 (41.1\%) & 0.052 \\
\hline 4 & 119 (57.8\%) & 78 (58.6\%) & 41 (56.2\%) & \\
\hline 5 & 17 (8.3\%) & 15 (1 1.3\%) & $2(2.7 \%)$ & \\
\hline
\end{tabular}

${ }^{*} p<0.05$, Fisher's exact test or Pearson's chi-square test. Data expressed in absolute frequency and percentage. HEl: Higher Education Institution; ENADE: National Exam of Student Performance; MEC: Ministry of Education of Brazil;

significantly higher in HEIs with doctoral $(p=0.041)$ and specialization programs $(\mathrm{p}=0.017)$ (Table 3).

Tutoring $(\mathrm{n}=211,89.4 \%)$, extension $(\mathrm{n}=216$, $91.5 \%)$, scientific initiation $(\mathrm{n}=89.4 \%)$, scientific events $(n=148,62.2 \%)$, scientific meetings organized by students ( $\mathrm{n}=197,82.8 \%)$, and institutional YouTube channels ( $n=158,66.4 \%$ ) were observed on the web pages of most dentistry courses included in this study. Only the presence of institutional YouTube channels was significantly associated with DE ( $p<0.001)$ (Table 4).

\section{Multivariate analysis: YouTube institutional channels and flattening of workload are the main indicators of distance classes in HEls with dentistry courses}

The unadjusted ORs from significant independent variables are shown in Table 5 . The binary regression model (multivariate analysis) showed that DSs in the southeast region $(\mathrm{p}<0.001)$ were most strongly associated with e-learning, showing a prevalence of 20.68 (95\% CI $=6.23-68.65)$ times higher DE availability. Lower workloads $(\leq 4,200 \mathrm{~h})$ were 3.32 
Table 3. Didactic-pedagogical profile of regulated dentistry courses with and without distance classes in Brazil.

\begin{tabular}{|c|c|c|c|c|}
\hline \multirow{2}{*}{ Variable } & \multirow{2}{*}{ Total } & \multicolumn{2}{|c|}{ Distance classes available } & \multirow{2}{*}{ p-valu } \\
\hline & & No & Yes & \\
\hline \multicolumn{5}{|c|}{ Accredidation request for $\mathrm{DE}$} \\
\hline No & $236(99.2 \%)$ & $156(100.0 \%)$ & $80(97.6 \%)$ & 0.070 \\
\hline Yes & $2(0.8 \%)$ & $0(0.0 \%)$ & $2(2.4 \%)$ & \\
\hline \multicolumn{5}{|l|}{ Total workload } \\
\hline$\leq 4,200 h$ & 104 (46.6\%) & $56(39.7 \%)$ & $48(58.5 \%)^{*}$ & 0.007 \\
\hline$>4,200 h$ & 119 (53.4\%) & $85(60.3 \%)^{*}$ & 34 (41.5\%) & \\
\hline \multicolumn{5}{|c|}{ Workload of optional subjects } \\
\hline$\leq 55 \mathrm{~h}$ & 103 (48.4\%) & $76(54.3 \%)^{*}$ & 27 (37.0\%) & 0.016 \\
\hline$>55 h$ & $110(51.6 \%)$ & $64(45.7 \%)$ & $46(63.0 \%)^{*}$ & \\
\hline \multicolumn{5}{|l|}{ Curriculum type } \\
\hline Subject-oriented & 124 (58.2\%) & $83(59.3 \%)$ & 41 (56.2\%) & 0.171 \\
\hline Modular & $24(11.3 \%)$ & $19(13.6 \%)$ & $5(6.8 \%)$ & \\
\hline Mixed & $65(30.5 \%)$ & $38(27.1 \%)$ & 27 (37.0\%) & \\
\hline \multicolumn{5}{|l|}{ Optional subjects } \\
\hline No & $16(7.5 \%)$ & $11(7.9 \%)$ & $5(6.8 \%)$ & 0.780 \\
\hline Yes & $196(92.5 \%)$ & $128(92.1 \%)$ & 68 (93.2\%) & \\
\hline \multicolumn{5}{|c|}{ Master's degree program } \\
\hline No & $127(53.4 \%)$ & 87 (55.8\%) & 40 (48.8\%) & 0.304 \\
\hline Yes & $111(46.6 \%)$ & $69(44.2 \%)$ & $42(51.2 \%)$ & \\
\hline \multicolumn{5}{|l|}{ Doctoral program } \\
\hline No & $157(66.0 \%)$ & 110 (70.5\%)* & 47 (57.3\%) & 0.041 \\
\hline Yes & 81 (34.0\%) & 46 (29.5\%) & $35(42.7 \%)^{*}$ & \\
\hline \multicolumn{5}{|l|}{ Specialization course } \\
\hline No & 76 (31.9\%) & $58(37.2 \%)^{*}$ & 18 (22.0\%) & 0.017 \\
\hline Yes & 162 (68.1\%) & 98 (62.8\%) & $64(78.0 \%)^{*}$ & \\
\hline
\end{tabular}

(95\% CI $=1.19-9.31)$ times more prevalent when DE was available ( $\mathrm{p}=0.022)$, and offering of optional subjects increased this prevalence by $6.66(95 \% \mathrm{CI}=1.17-37.97)$ times $(p=0.033)$. The presence of YouTube channels was also directly associated with DE with an adjusted odds ratio of 6.37 (95\% CI =1.76-22.97) times ( $p=0.005)$. These variables were independently associated with the presence of distance classes in dentistry courses.

\section{Discussion}

This study showed that most dentistry courses with DE in Brazil are concentrated in the southern macro-regions and private schools, have institutional
YouTube channels, and are inversely associated with total workload and ENADE scores. Currently, the National Curricular Guidelines (NCD) implemented for undergraduate courses in dentistry since 2002 are responsible for reorganizing and reformulating the pedagogical projects of HEIs in Brazil and do not permit the establishment of dentistry courses in a fully DE format, as a major part of the workload of dentistry courses is devoted to face-to-face activities. ${ }^{19}$ However, in December 6, 2019, through ordinance No. 2117, the MEC authorized universities to offer up to $40 \%$ of the workload through distance learning in undergraduate courses in the health field, including dentistry. ${ }^{20}$ 
Table 4. Profile of the extracurricular activities and programs and presence of Youtube channels in regulated dentistry courses with and without distance classes in Brazil.

\begin{tabular}{|c|c|c|c|c|}
\hline \multirow{2}{*}{ Variable } & \multirow{2}{*}{ Total } & \multicolumn{2}{|c|}{ Distance classes available } & \multirow{2}{*}{$\mathrm{p}$-value } \\
\hline & & No & Yes & \\
\hline \multicolumn{5}{|c|}{ Tutoring program } \\
\hline No & $25(10.6 \%)$ & $16(10.4 \%)$ & $9(11.0 \%)$ & 0.889 \\
\hline Yes & $211(89.4 \%)$ & $138(89.6 \%)$ & $73(89.0 \%)$ & \\
\hline \multicolumn{5}{|c|}{ Extension program } \\
\hline No & $20(8.5 \%)$ & $14(9.1 \%)$ & $6(7.3 \%)$ & 0.641 \\
\hline Yes & $216(91.5 \%)$ & 140 (90.9\%) & $76(92.7 \%)$ & \\
\hline \multicolumn{5}{|c|}{ Scientific initiation program } \\
\hline No & $25(10.6 \%)$ & $14(9.1 \%)$ & $11(13.4 \%)$ & 0.304 \\
\hline Yes & $211(89.4 \%)$ & 140 (90.9\%) & $71(86.6 \%)$ & \\
\hline \multicolumn{5}{|c|}{ Scientific events } \\
\hline No & $90(37.8 \%)$ & $54(34.6 \%)$ & $36(43.9 \%)$ & 0.160 \\
\hline Yes & $148(62.2 \%)$ & 102 (65.4\%) & $46(56.1 \%)$ & \\
\hline \multicolumn{5}{|c|}{ Scientific meetings organized by students } \\
\hline No & $41(17.2 \%)$ & 27 (17.3\%) & $14(17.1 \%)$ & 0.964 \\
\hline Yes & $197(82.8 \%)$ & 129 (82.7\%) & $68(82.9 \%)$ & \\
\hline \multicolumn{5}{|c|}{ Institutional Youtube channels } \\
\hline No & $80(33.6 \%)$ & $70(44.9 \%)^{*}$ & $10(12.2 \%)$ & $<0.001$ \\
\hline Yes & $158(66.4 \%)$ & $86(55.1 \%)$ & $72(87.8 \%)^{*}$ & \\
\hline
\end{tabular}

Face-to-face learning remains invaluable for the integration of theory and clinical practice. ${ }^{21}$ However, given the impossibility of maintaining in-class teaching, dentistry courses in Brazil were forced to virtualize theoretical classes to enable the continuity of teaching activities. 5,6 This scenario of teaching dentistry through digital platforms draws attention to a particular issue: would it be possible to adapt a part of the core curriculum of DS to a permanent DE format?

E-learning systems have been used for some time in dental schools in Europe ${ }^{8}$ and in developing countries such as South Africa, where the digitization of higher education has been increasing in recent years despite difficulties with Internet access. ${ }^{22}$ Several e-learning models have been developed worldwide; ${ }^{23}$ therefore, there is an urgent need to develop skills and competencies to adapt to distance learning in dentistry.

As previously described, most dentistry courses in the country are in the southeast region. ${ }^{24}$ This region also encompasses most dentistry courses offering DE, which was expected, as it is described as the most advanced in the process of DE in HEIs. ${ }^{25}$ It is the wealthiest region in the country and enables the private sector in higher education to increase investments in virtual platforms, thus offering a greater number of DE programs.

However, students in the DE program exhibited lower ENADE scores. The effectiveness of DE for undergraduate dentistry courses is still debatable, and it is necessary to pay attention to this result. ${ }^{26}$ The private education network is strongly associated with capital production, which may lead to investments in less costly and underperforming platforms, ${ }^{19}$ thus directly impacting the quality of the teachinglearning process. ${ }^{27}$

DE still receives much criticism regarding its quality and credibility. This requires the establishment of protocols to guide publications that would avoid inconsistencies in the quality of 
Table 5. Multivariate analysis of factors associated with increased prevalence of dentistry courses in Brazil offering distance classes.

\begin{tabular}{|c|c|c|c|}
\hline \multirow{2}{*}{ Distance classes availability } & Unajusted OR & \multirow{2}{*}{$p$-value } & \multirow{2}{*}{$\begin{array}{c}\text { Ajusted OR } \\
(95 \% \mathrm{Cl})\end{array}$} \\
\hline & $(95 \% \mathrm{Cl})$ & & \\
\hline Southeast region & $10.66(5.67-20.06)$ & $<0.001$ & $20.68(6.23-68.65)$ \\
\hline HEI funding (Private schools) & $4.37(1.77-10.80)$ & 0.053 & $7.35(0.97-55.58)$ \\
\hline Years of activitiy of the dentistry course (> 20 years) & $1.55(0.90-2.66)$ & 0.371 & $1.62(0.56-4.65)$ \\
\hline Seats offered $(>100)$ & $1.38(0.79-2.40)$ & 0.218 & $2.01(0.66-6.13)$ \\
\hline ENADE score $(\leq 3)$ & $2.91(1.42-5.94)$ & 0.057 & $3.89(0.96-15.79)$ \\
\hline MEC grade $(\leq 3)$ & $1.62(0.89-2.94)$ & 0.460 & $1.51(0.51-4.46)$ \\
\hline Accredidation request for $\mathrm{DE}$ & $9.72(0.46-205)$ & 0.999 & $1.92(0.10-20.00)$ \\
\hline Total workload $(\leq 4,200 \mathrm{~h})$ & $2.14(1.23-3.73)$ & 0.022 & $3.32(1.19-9.31)$ \\
\hline Optional subjects workload (>55h) & $2.02(1.13-3.61)$ & 0.688 & $1.26(0.40-3.98)$ \\
\hline Curriculum type (Mixed/Modular) & $1.14(0.64-2.01)$ & 0.190 & $2.21(0.67-7.24)$ \\
\hline Optional subject & $1.17(0.39-3.50)$ & 0.033 & $6.66(1.17-37.97)$ \\
\hline Master's degree program & $1.32(0.77-2.26)$ & 0.600 & $1.56(0.29-8.34)$ \\
\hline Doctoral program & $1.78(1.02-3.11)$ & 0.478 & $1.83(0.35-9.65)$ \\
\hline Speciliazation courses & $2.10(1.14-3.89)$ & 0.869 & $1.10(0.35-3.50)$ \\
\hline Tutoring program & $1.06(0.45-2.52)$ & 0.612 & $2.12(0.12-38.60)$ \\
\hline Extension program & $1.27(0.47-3.43)$ & 0.688 & $1.87(0.09-39.40)$ \\
\hline Scientific initation program & $1.55(0.67-3.59)$ & 0.821 & $1.38(0.08-23.04)$ \\
\hline Scientific events & $1.48(0.86-2.55)$ & 0.950 & $1.03(0.38-2.82)$ \\
\hline Scientific meetings organized by students & $1.02(0.50-2.07)$ & 0.483 & $1.62(0.42-6.29)$ \\
\hline Institutional Youtube channels & $5.86(2.82-12.20)$ & 0.005 & 6.37 (1.76-22.97) \\
\hline
\end{tabular}

the content offered by these platforms. Protocols such as the Guidelines for Medical and Health Information on the Internet and the Health on the Net Foundation serve as guidelines for the quality of healthcare content on the Internet. In the United Kingdom, similar initiatives are promoted by the British Medical Journal in partnership with the British Medical Association..$^{28}$ Therefore, mechanisms to control the quality of this teaching model in Brazil are also necessary.

Despite these limitations, DE is a process that has been shown to improve the quality of courses in the health field. Recently, Brazil participated in a large multicenter trial that evaluated the integration of an e-learning system in health care, which demonstrated superior results for groups who adopted e-learning over those who continued to implement traditional teaching methods. ${ }^{29}$ Local studies have also shown that DE can achieve equal or even higher levels of learning than in-class teaching. ${ }^{30}$ However, teachers and students need to adapt to this teaching model, as it requires students to be responsible for their own learning process in an autonomous way. ${ }^{31}$

DE needs student autonomy; therefore, optional subjects and lower workloads are beneficial to students in HEIs with DE platforms. This approach has also shown similar levels of satisfaction among students as the traditional classroom approach..$^{32}$ A reduction in workload combined with an increase in flexibility of the teaching process in dentistry courses has demonstrated a significant association with stress reduction in dental students. ${ }^{33}$ This might partially explain the relationship observed in our study because flexibility is the most important factor for student adherence to DE practices. ${ }^{26}$ 
This study also found that dentistry courses at HEIs with specialization and postgraduate programs were directly associated with greater availability of distance classes in undergraduate courses. The DE modality in dentistry is especially adopted by postgraduate and specialization programs as well as refresher courses. Consequently, the presence of postgraduate programs could be an indicator that favors the implementation of these teaching technologies in undergraduate courses. ${ }^{34}$

Of all the indicators, the presence of institutional YouTube channels was the factor most strongly associated with the offering of distance classes in the dentistry courses evaluated in our study. The inclusion of social networks in the teaching process is well received by dentistry students, ${ }^{35}$ especially because this student category strongly adheres to these technologies. ${ }^{36}$ Social networks are also part of the infinite tools of the virtual teaching and learning process, especially in a generation prone to knowledge assimilation through new technologies. ${ }^{34}$

However, the acceptance of DE among teachers is quite different. Low acceptance of technological advancements and lack of knowledge in managing virtual tools ${ }^{37}$ hinder the implementation of curricular and technological innovations in dentistry courses. ${ }^{12} \mathrm{~A}$ recent systematic review showed that organizational, economic, software, hardware, and support barriers play a major role in generating resistance to the implementation of e-learning for health professionals. Psychological resistance to change is also one of the biggest obstacles in the adoption of DE in health education, which also generates pedagogical issues that affect DE implementation. ${ }^{38}$

$\mathrm{DE}$ is an important asset in the democratization of the teaching-learning process. ${ }^{39}$ Although infrastructural, technological, and psychological barriers to the implementation of distance learning in dentistry still exist, the COVID-19 pandemic has shown that we have taken a big step toward this process. We expect an increase in the number of dental schools with distance learning after the pandemic, especially due to this forced transition and the low cost of this teaching method. ${ }^{40}$

However, our findings should be interpreted with caution due to its limitations. The major limitation of this study is that most HEIs with dental schools were not included because they were still in the curriculum consolidation phase, and the fact that many institutions during May and June (data collection period) were planning for remote activities and did not make public information available. Therefore, these data could introduce significant bias in the results and greatly modify the outcomes. Thus, we recommend that similar studies be reproduced in the future when most of these HEIs will have consolidated dentistry courses. Even with these limitations, we report an important finding: low academic performance was directly associated with e-learning, and if official regulatory conducts are not performed, as in England, ${ }^{28}$ the quality dental education in Brazil may deteriorate. ${ }^{41}$ Other important limitations are that many different and novel forms of e-learning were developed after the suspension of classes; however, in this study, they were grouped under e-learning. This grouping increases the amplitude of screening (national level) but decreases the sensitivity of identifying risk factors for poor quality of learning in dentistry. Future studies are needed to investigate the influence of different types of e-learning on the quality of DS.

The major supporters of e-learning in Brazil are private dental schools..$^{42}$ They need continuous professional education and employment stability to implement and maintain e-learning in dentistry. ${ }^{43,44}$ Dentistry teachers should be encouraged in implementing this teaching method, leading to improvements in the levels of engagement and activity of educators, which is the strongest predictor of professional development in higher education. ${ }^{45}$

\section{Conclusion}

More than one-third of the dentistry courses evaluated in this study offered distance classes, and considering that the presence of digital media channels was an important predictor, an increase in the offering of this teaching modality is expected in all dentistry courses in Brazil after the quarantine period ends. Nevertheless, the association between distance learning and low academic performance has drawn attention to the need for regulatory bodies for controlling the quality of the content available in DE. 


\section{References}

1. Zhu N, Zhang D, Wang W, Li X, Yang B, Song J, et al. A novel coronavirus from patients with pneumonia in China, 2019. N Engl J Med. 2020 Feb;382(8):727-

2. Omary MB, Eswaraka J, Kimball SD, Moghe PV, Panettieri RA Jr, Scotto KW. The COVID-19 pandemic and research shutdown: staying safe and productive. J Clin Invest. 2020 Jun;130(6):2745-8. https://doi.org/10.1172/JCl138646

3. Fleming J, Becker K, Newton C. Factors for successful e-learning: does age matter? Educ Train. 2017 Jun;59(1):76-89. https://doi.org/10.1108/ET-07-2015-0057

4. Koo JR, Cook AR, Park M, Sun Y, Sun H, Lim JT, et al. Interventions to mitigate early spread of SARS-CoV-2 in Singapore: a modelling study. Lancet Infect Dis. 2020 Jun;20(6):678-88. https://doi.org/10.1016/S1473-3099(20)30162-6

5. Ministério da Educação (BR). Portaria $N^{\circ} 343$, de 17 de março de 2020. Dispõe sobre a substituição das aulas presenciais por aulas em meios digitais enquanto duras a situação de pandemia - COVID-19. Diário Oficial União. 2020 Mar 18.

6. Ministério da Educação (BR). Portaria $N^{\circ} 544$, de 16 de junho de 2020. Dispõe sobre a substituição das aulas presenciais por aulas em meios digitais, enquanto durar a situação de pandemia do novo coronavírus - Covid-19. Diário Oficial União. 2020 Jun 17.

7. Franco LL, Soares EF, Martorell LB, Marcelo VC. The teacher of the dentistry course: his education and the challenges. Rev Prof Docente. 2009;9(20):57-74. https://doi.org/10.31496/rpd.v9i20.235

8. Nattestad A, Attstrom R, Mattheos N, Ramseier C, Canegallo L, Eaton K, et al. 4.1 Web-based interactive learning programmes. Eur J Dent Educ. 2002;6(3 Suppl 3):127-37. https://doi.org/10.1034/j.1600-0579.6.s3.17.x

9. Cruz AD, Costa JJ, Almeida SM. Distance learning in dental radiology: immediate impact of the implementation. 2014 OctDec;17(4):90-7. https://doi.org/10.14295/bds.2014.v17i4.930

10. Hannay M, Newvine M. Perceptions of distance learning: a comparison of online and traditional learning. J Online Learn Teach. 2006;2(1):1-11.

11. Dickey MD. The impact of web-logs (blogs) on student perceptions of isolation and alienation in a web-based distance-learning environment. Open Learn. 2004;19(3):279-91. https://doi.org/10.1080/0268051042000280138

12. Hendricson WD, Cohen PA. Future directions in dental school curriculum, teaching, and learning. In: Tedesco L, Haden K. Leadership for the future: the dental school in the university. Washington, DC: American Association of Dental Schools; 1999. p. 37-62.

13. Wainer J, Vieira P, Melguizo T. The association between having access to computers and Internet and educational achievement for primary students in Brazil. Comp Educ. 2015 Jan;80:68-76. https://doi.org/10.1016/i.compedu.2014.08.007

14. Koohang A, Durante A. Learners' perceptions toward the web-based distance learning activities/assignments portion of an undergraduate hybrid instructional model. J Inf Technol Educ. 2003;2(1):105-13. https://doi.org/10.28945/316

15. Malta M, Cardoso LO, Bastos FI, Magnanini MM, Silva CM. STROBE initiative: guidelines on reporting observational studies. Rev Saude Publica. 2010 Jun;44(3):559-65. https://doi.org/10.1590/S0034-89102010000300021

16. Johnston JM, Leung GM, Fielding R, Tin KY, Ho LM. The development and validation of a knowledge, attitude and behaviour questionnaire to assess undergraduate evidence-based practice teaching and learning. Med Educ. 2003 Nov;37(11):992-1000. https://doi.org/10.1046/i.1365-2923.2003.01678.x

17. Yu S, Yang KF. Attitudes toward Web-based distance learning among public health nurses in Taiwan: a questionnaire survey. Int J Nurs Stud. 2006 Aug;43(6):767-74. https://doi.org/10.1016/j.ijnurstu.2005.09.005

18. Andrews KG, Demps EL. Distance education in the U.S. and Canadian undergraduate dental curriculum. J Dent Educ. 2003 Apr;67(4):427-38. https://doi.org/10.1002/i.0022-0337.2003.67.4.tb03644.x

19. Fonseca EP. [The National Curriculum Guidelines and training of brazilian dentists]. J Manag Prim Health Care. 2012 Oct;3(2):158-78. Portuguese. https://doi.org/10.14295/jmphc.v3i2.154

20. Ministério da Educação (BR). Portaria №2.117, de 6 de dezembro de 2019. Dispõe sobre a oferta de carga horária na modalidade de Ensino a Distância - EaD em cursos de graduação presenciais ofertados por Instituições de Educação Superior - IES pertencentes ao Sistema Federal de Ensino. Diário Oficial União. 2019 Dec 7.

21. Lamers JMS, Baumgarten A, Bittencourt FV, Toassi RF. Mudanças curriculares na educação superior em Odontologia: inovações, resistências e avanços conquistados. Rev ABENO. Dez. 2016;16(4):2-18. https://doi.org/10.30979/rev.abeno.vl6i4.324

22. Ravjee N. The politics of e-learning in South African higher education. Int J Educ Dev Using Inf Commun Technol. 2007 Aug;3(4):27-41.

23. Ruggeri K, Farrington C, Brayne C. A global model for effective use and evaluation of e-learning in health. Telemed J E Health. 2013 Apr;19(4):312-21. https://doi.org/10.1089/tmj.2012.0175

24. Martin AS, Chisini LA, Martelli S, Sartori LR, Ramos EC, Demarco FF. Distribution of Dental Schools and dentists in Brazil: an overview of the labor Market. Rev ABENO. 2018 Jul;18(1):63-73. https://doi.org/10.30979/rev.abeno.v18i1.399

25. Silva AR, Nunes CS, Spanhol FJ, Santos JV, Rabelo S. [Models used for distance education: an overview focused on higher education institutions of Brazil]. Rev GUAL. 2011 Sep/Dec;4(3):153-69. Portuguese. https://doi.org/10.5007/1983-4535.2011v4n3p153 
Distance education in dentistry in Brazil: a critical STROBE-based analysis

26. Sales LN, Nascimento LS, Brandão GA, Magalhães AC, Pontes FS. [Distance education and use of information technology for an education in dentistry: the student's perception]. Rev ABENO. 2012 Dec;12(2):227-32. Portuguese. https://doi.org/10.30979/rev.abeno.v12i2.128

27. Woelber JP, Hilbert TS, Ratka-Krüger P. Can easy-to-use software deliver effective e-learning in dental education? A randomised controlled study. Eur J Dent Educ. 2012 Aug;16(3):187-92. https://doi.org/10.1111/i.1600-0579.2012.00741.x

28. Christante L, Ramos MP, Bessa R, Sigulem D. [The role of distance education in continuing medical education: a critical review]. Rev Assoc Med Bras. 2003 Jul-Sep;49(3):326-9. Portuguese. https://doi.org/10.1590/S0104-42302003000300039

29. Kulier R, Gülmezoglu AM, Zamora J, Plana MN, Carroli G, Cecatti JG, et al. Effectiveness of a clinically integrated e-learning course in evidence-based medicine for reproductive health training: a randomized trial. JAMA. 2012 Dec;308(21):2218-25. https://doi.org/10.1001/jama.2012.33640

30. Barros MM, Borges Neto H, Sousa MS, Silva PG, Teixeira CN, Almeida ME. Digital information and communication technologies as a support to the Internship in Dentistry. Rev ABENO. 2019 Jun;19(2):117-26. https://doi.org/10.30979/rev.abeno.v19i2.670

31. Santos CM, Bulgarelli PT, Frichembruder K, Colvara BC, Hugo FN. [Evaluation of the learning quality in the virtual environment (Moodle) in oral health, in the students' perspective]. Rev ABENO. 2018 Sep;18(1):116-23. Portuguese. https://doi.org/10.30979/rev.abeno.v18i1.433

32. Allen M, Bourhis J, Burrell N, Mabry E. Comparing student satisfaction with distance education to traditional classrooms in higher education: a meta-analysis. Am J Distance Educ. 2002 Jun;16(2):83-97. https://doi.org/10.1207/S15389286AJDE1602_3

33. Alzahem AM, Van der Molen HT, Alaujan AH, De Boer BJ. Stress management in dental students: a systematic review. Adv Med Educ Pract. 2014 May;5:167-76. https://doi.org/10.2147/AMEP.S46211

34. Silva AN, Santos AM, Cortez EA, Cordeiro BC. Limits and possibilities of distance learning in continuing education in health: integrative review. Cienc Saúde Colet. 2015 Apr;20(4):1099-07. https://doi.org/10.1590/1413-81232015204.17832013

35. Souza FB, Lopes MGQ, Filho RML. Social networks in dental training: opinion of students from a Brazilian university. Rev Cuba Estomatol. 2017 Apr-Jun;54(2):1-11.

36. Kenny P, Johnson IG. Social media use, attitudes, behaviours and perceptions of online professionalism amongst dental students. Br Dent J. 2016 Nov;221(10):651-5. https://doi.org/10.1038/sj.bdj.2016.864 PMID:27857111

37. Ramos ER, Souza FB, Melo MM. Incorporation of information and communication technologies in the teaching-service integration of health courses of a public university. Rev ABENO. 2018 Jul;18(3):159-68. https://doi.org/10.30979/rev.abeno.v18i3.580

38. Childs S, Blenkinsopp E, Hall A, Walton G. Effective e-learning for health professionals and students-barriers and their solutions: a systematic review of the literature-findings from the HeXL project. Health Info Libr J. 2005 Dec;22(s2 Suppl 2):20-32. https://doi.org/10.1111/j.1470-3327.2005.00614.x

39. Martinez-Mier EA, Soto-Rojas AE, Stelzner SM, Lorant DE, Riner ME, Yoder KM. An international, multidisciplinary, service-learning program: an option in the dental school curriculum. Educ Health (Abingdon). 2011 Apr;24(1):259.

40. Frehywot S, Vovides Y, Talib Z, Mikhail N, Ross H, Wohltien H, et al. E-learning in medical education in resource constrained low- and middle-income countries. Hum Resour Health. 2013 Feb;11(1):4. https://doi.org/10.1186/1478-4491-11-4

41. Aamodt PO, Havnes A. Factors affecting professional job mastery: quality of study or work experience? Qual High Educ. 2008;14(3):233-48. https://doi.org/10.1080/13538320802507539

42. Fonseca EP, Rocha CM, Kruger E, Tennant M, Mialhe FL, Meneghim MC. Distribution of dental schools in Brazil, 2015. Eur J Gen Dent. 2016;5(2):47-52. https://doi.org/10.4103/2278-9626.179534

43. Zhukovskiy YL, Vasilev BU, Koteleva N. Quality estimation of continuing professional education of technical specialists. 2017 Int Conf "Quality Management, Transport and Information Security, Information Technologies" (IT\&QM\&IS). 2017;1 (1):704-7. https://doi.org/10.1109/ITMQIS.2017.8085921

44. Çınkır S, Kurum G. Discrepancy in teacher employment: the problem of out-of-field teacher employment. J Int Soc Educ Plann. $2015 ; 22(1): 29: 40$.

45. Shaha SH, Ellsworth H. Predictors of success for professional development: linking student achievement to school and educator successes through on-demand, online professional learning. J Instruc Psychol. 2013 Mar;40(1):19-26. 